\title{
DAMPAK PEMANFAATAN BEASISWA BIDIKMISI MAHASISWA PROGRAM STUDI PENDIDIKAN SOSIOLOGI UNIVERSITAS NEGERI MAKASSAR
}

\author{
Ayu Septian', M. Ridwan Said Ahmad² \\ 1,2Program Studi Pendidikan Sosiologi, Fakultas Ilmu Sosial, Universitas Negeri Makassar \\ septianayu@gmail.com ${ }^{1}$, m.ridwan.said.ahmad@unm.ac.id ${ }^{2}$
}

\begin{abstract}
ABSTRAK
Penelitian ini bertujuan untuk mengetahui; 1) Pemanfaatan beasiswa bidikmisi pada mahasiswa Program Studi Pendidikan Sosiologi Universitas Negeri Makassar. 2) Dampak pemanfaatan beasiswa bidikmisi pada mahasiswa Program Studi Pendidikan Sosiologi Universitas Negeri Makassar. Jenis penelitian yang digunakan adalah kualitatif deskriptif. Teknik penentuan informan adalah purposive sampling, dengan informan berjumlah 12 orang dengan kriteria yaitu mahasiswa Pendidikan Sosiologi UNM penerima beasiswa bidikmisi angkatan 2015-2018 yang berstatus aktif kuliah, mahasiswa yang nilai IPKnya meningkat, dan mahasiswa yang nilai IPKnya menurun. Teknik pengumpulan data yang digunakan yaitu observasi, wawancara, dan dokumentasi. Data yang diperoleh dalam penelitian ini kemudian dianalisis dengan tahapan kondensasi data, model data, dan penarikan kesimpulan. Teknik pengabsahan data menggunakan member check. Hasil penelitian menunjukkan bahwa, 1) Mahasiswa Pendidikan Sosiologi UNM penerima beasiswa bidikmisi memanfaatkan beasiswa bidikmisinya untuk memenuhi (a) kebutuhan akademik seperti kebutuhan sarana pembelajaran misalnya membeli buku, alat tulis, laptop, serta biaya print dan foto copy, (b) kebutuhan non akademik seperti kebutuhan sehari-hari, fashion, membeli handphone, traktir teman, transportasi dan pulsa/paket data. 2) Dampak dari pemanfaatan beasiswa bidikmisi terhadap mahasiswa Program Studi Pendidikan Sosiologi UNM terdiri atas dampak positif dan negatif. Adapun dampak positifnya, yaitu meningkatkan motivasi belajar. Sedangkan dampak negatifnya yaitu nilai IPK menurun dan perilaku konsumtif meningkat.
\end{abstract}

Kata kunci: Dampak, Pemanfaatan, Beasiswa

\section{ABSTRACT}

This study aims to determine; 1) Utilization of Bidikmisi scholarships to students of the Sociology Education Study Program at Makassar State University. 2) The impact of using Bidikmisi scholarships on students of the Sociology Education Study Program at Makassar State University. This type of research is descriptive qualitative. The technique for determining informants was purposive sampling, with 12 informants with criteria, namely the Sociology Education students of UNM who received the 2015-2018 bidikmisi scholarship as active college students, students whose GPA scores increased, and students whose GPA grades decreased. Data collection techniques used are observation, interviews, and documentation. Data obtained in this study were then analyzed by data condensation stages, data models, and drawing conclusions. The data validation technique is using member check. The results showed that, 1) UNM Sociology Education Student recipient of bidikmisi scholarship utilizes his bidikmisi scholarship to meet (a) academic needs such as learning facilities such as buying books, stationery, laptops, and the cost of printing and photocopying, (b) non-academic needs such as daily necessities, fashion, buying mobile phones, treating friends, transportation and credit / data packages. 2) The impact of the use of Bidikmisi scholarships to students of the UNM Sociology Education Study Program consists of positive and negative impacts. The positive impact, which is to increase learning motivation. While the negative impact is the value of the CPI decreases and consumer behavior increases.

Keywords: Impact, Utilization, Scholarships

\section{PENDAHULUAN}

Pendidikan merupakan usaha sadar untuk mewujudkan proses pembelajaran agar peserta didik mengembangkan potensi dirinya sehingga memiliki keterampilan. Keberlangsungan pendidikan sangat dipengaruhi oleh latar belakang ekonomi. Latar 
belakang ekonomi yang rendah membuat peserta didik tidak bisa melanjutkan pendidikan ke perguruan tinggi karena biaya yang diperlukan untuk melanjutkan pendidikan ke perguruan tinggi mahal. Oleh sebab itu, pemerintah memberikan berbagai kemudahan untuk masyarakat kurang mampu serta memiliki prestasi yang ingin melanjutkan pendidikan di perguruan tinggi. Salah satu kemudahan yang diberikan oleh pemerintah ialah dengan adanya berbagai macam beasiswa pendidikan yang telah disiapkan untuk penerus bangsa salah satunya yaitu beasiswa bidikmisi (Rachmawaty, 2016).

Bidikmisi yaitu bantuan biaya pendidikan bagi calon mahasiswa tidak mampu secara ekonomi dan memiliki potensi akademik baik untuk menempuh pendidikan di perguruan tinggi pada program studi unggulan sampai lulus tepat waktu (Juliardi, 2017). Pemberian beasiswa bidikmisi diberikan sejak calon mahasiswa dinyatakan lulus di perguruan tinggi sampai batas waktu studi mahasiswa yang ditentukan. Namun, pemberian beasiswa bidikmisi akan dihentikan apabila mahasiswa tersebut tidak dapat memenuhi syarat yang ditetapkan oleh perguruan tinggi, salah satunya memperoleh Indeks Prestasi (IP) minimal 3,00. Adapun ketentuan khusus penghentian pemberian bantuan secara umum yaitu apabila mahasiswa penerima cuti, drop out, dan non aktif. Hal-hal yang dapat diatur diketentuan khusus antara lain.

Mahasiswa bidikmisi yang terbukti memberikan keterangan data diri yang tidak benar setelah diterima diperguruan tinggi, mahasiswa bidikmisi yang mengundurkan diri, mahasiswa yang meninggal dunia, mahasiswa yang lulus kurang dari masa studi yang ditetapkan dan penggantian penerima bidikmisi kepada mahasiswa lain. Universitas telah memberikan kemudahan bagi masyarakat yang kurang mampu terutama dalam finansial tetapi memiliki berbagai prestasi. Salah satu perguruan tinggi yang dipercayai untuk memberikan beasiswa adalah Universitas Negeri Makassar (UNM) salah satunya yaitu beasiswa bidikmisi. Di Universitas Negeri Makassar mahasiswa penerima beasiswa bidikmisi tersebar disemua fakultas yang ada salah satunya yaitu Fakultas Ilmu Sosial (FIS) jurusan Pendidikan Sosiologi.

Melalui program beasiswa bidikmisi pemerintah siap menanggung biaya kuliah dan biaya hidup bagi penerima beasiswa tersebut. Para penerima program beasiswa bidikmisi akan lebih terjamin dan dapat mengikuti pendidikan tanpa harus memikirkan biaya. Hal tersebut akan membangun jiwa generasi muda untuk lebih berpacu dalam menempuh pendidikan yang lebih tinggi lagi dan melakukan berbagai inovasi kreatif yang bermanfaat. Selain mendapatkan berbagai fasilitas dari universitas, para penerima beasiswa bidikmisi pun selalu diikutsertakan dalam berbagai kegiatan yang diadakan oleh universitas. Perbedaan program beasiswa bidikmisi dengan beasiswa lainnya di Universitas Negeri Makassar di antaranya penerima beasiswa bidikmisi mendapatkan batuan meliputi bantuan penyelenggaraan pendidikan dan bantuan biaya hidup per semester.

Adapun bantuan biaya penyelenggaraan pendidikan sebesar Rp 2.400.000,00 per semester per mahasiswa dan bantuan biaya hidup dibayarkan ke rekening mahasiswa sebesar Rp. 4.200.000,00 per semester per mahasiswa. Adanya beasiswa bidikmisi diharapkan dipergunakan dengan baik oleh penerimanya untuk menunjang pendidikan selama menempuh perkuliahan seperti membeli buku dan kebutuhan lainnya yang menunjang pendidikan. Tetapi kenyataannya ada mahasiswa penerima beasiswa bidikmisi yang mempergunakan beasiswanya tidak hanya untuk menunjang kebutuhan yang menyangkut pendidikan selama menempuh pendidikan tetapi mahasiswa yang menggunakan beasiswa yang diterimanya untuk mentraktir temannya, memenuhi gaya hidupnya yang mengarah ke gaya hidup hedonis. 


\section{METODE PENELITIAN}

Berdasarkan rumusan masalah dan tujuan penelitian yang telah ditetapkan maka jenis penelitian yang digunakan dalam penelitian ini adalah jenis kualitatif dengan pendekatan deskriptif. Lokasi pada penelitian ini yaitu di Fakultas Ilmu Sosial Universitas Negeri Makassar yang beralamat di Jl. Pendidikan, Kelurahan Tidung, Kecamatan Rappocini, Kota Makassar, Sulawesi Selatan 90221.

Teknik penentuan informan adalah purposive sampling, dengan informan berjumlah 12 orang dengan kriteria yaitu mahasiswa Pendidikan Sosiologi UNM penerima beasiswa bidikmisi angkatan 2015-2018 yang berstatus aktif kuliah, mahasiswa yang nilai IPKnya meningkat, dan mahasiswa yang nilai IPKnya menurun. Sumber data dalam penelitian ini adalah data primer dan data sekunder. Teknik pengumpulan data yang digunakan yaitu observasi, wawancara, dan dokumentasi. Data yang diperoleh dalam penelitian ini kemudian dianalisis dengan tahapan kondensasi data, model data, dan penarikan kesimpulan. Teknik pengabsahan data menggunakan member check. Member check merupakan "pengecekan data yang diperoleh penulis kepada pemberi data".

\section{HASIL PENELITIAN DAN PEMBAHASAN}

\section{Pemanfaatan Beasiswa Bidikmisi}

Dalam hal ini adalah bagaimana proses, cara, perbuatan mahasiswa penerima beasiswa bidikmisi dalam memanfaatkan atau mengolah dana beasiswa bidikmisi yang diberikan oleh pemerintah dalam memenuhi kebutuhannya selama menempuh pendidikan. Berdasarkan hasil penelitian yang telah dilakukan penulis bahwa mahasiswa penerima beasiswa bidikmisi memanfaatkan dana beasiswa bidikmisinya untuk kebutuhan akademik dan non akademik.

\section{a. Kebutuhan Akademik}

Sebagai mahasiswa tentu banyak keperluan akademik yang dibutuhkan untuk menunjang pendidikan selama mahasiswa tersebut menempuh pendidikan. Kebutuhan akademik mahasiswa terdiri dari buku, alat tulis, laptop, biaya print, dan foto copy. Kebutuhan tersebut harus dipenuhi oleh mahasiswa selama menempuh pendidikannya.

Dari hasil penelitian menunjukkan bahwa informan yang merupakan mahasiswa penerima beasiswa bidikmisi pada Program Studi Pendidikan Sosiologi memanfaatkan dana beasiswa yang diterima untuk keperluan yang menunjang akademik seperti membeli buku, membeli alat tulis yang dapat digunakan selama proses pembelajaran, dan membeli laptop sebagai alat yang memudahkan mahasiswa dalam mengerjakan tugas. Memiliki buku pembelajaran, alat tulis dan laptop akan membantu dan memudahkan mahasiswa dalam proses pembelajaran, sehingga mahasiswa penerima beasiswa bidikmisi lebih mudah dalam mencari dan mendapatkan materi-materi yang berkaitan dengan pembelajarannya dan lebih mudah dalam mengerjakan tugas-tugas kuliah. Serta adanya dana beasiswa bidikmisi tersebut maka mahasiswa penerima beasiswa bidikmisi tidak lagi merasa sulit untuk biaya foto copy dan print sehingga mahasiswa penerima beasiswa bidikmisi tersebut dapat memenuhi kebutuhan akademik dengan baik dan tercukupi yang akan meningkatkan prestasi akademiknya. Hal ini didukung oleh pendapat ahli bahwa "sarana belajar adalah peralatan belajar yang dibutuhkan dalam proses belajar agar pencapaian tujuan belajar dapat berjalan dengan lancar, teratur, efektif dan efisien".

\section{b. Kebutuhan Non Akademik}

Pada pembahasan ini mengenai pemanfaatan beasiswa bidikmisi oleh mahasiswa Program Studi Pendidikan Sosiologi Universitas Negeri Makassar. Pemanfaatannya yaitu 
digunakan untuk memenuhi kebutuhan non akademik. Keperluan non akademik mahasiswa terdiri dari kebutuhan sehari-hari, fashion, handphone, dan traktir teman.

Pertama, kebutuhan sehari-hari. Kebutuhan sehari-hari mahasiswa penerima beasiswa bidikmisi merupakan kebutuhan non akademik yang dipenuhi selama masih menempuh pendidikan. Kebutuhan sehari-hari merupakan kebutuhan hidup mahasiswa penerima beasiswa bidikmisi selama masih menempuh pendidikan di Perguruan Tinggi Negeri. Yang termasuk dalam kebutuhan sehari-hari mahasiswa penerima beasiswa bidikmisi antara lain biaya tempat tinggal, biaya makan dan biaya untuk kebersihan dirinya. Kebutuhan-kebutuhan tersebut harus dapat dipenuhi oleh mahasiswa penerima beasiswa bidikmisi untuk bertahan hidup. Hal ini sesuai dengan pendapat Abraham Maslow bahwa "kebutuhan dasar yang harus dipenuhi yaitu kebutuhan fisiologis. Kebutuhan fisiologis merupakan kebutuhan mutlak yang harus dipenuhi oleh manusia untuk bertahan hidup seperti sandang, pangan dan papan".

Kedua, kebutuhan fashion. Kebutuhan fashion merupakan kebutuhan non akademik yang dapat membentuk pola hidup mahasiswa penerima beasiswa bidikmisi. Kebutuhan dalam hal ini ialah kebutuhan untuk membeli baju, membeli sepatu dan membeli tas guna untuk menunjang penampilan seseorang. Hal ini dapat dilihat bahwa mahasiswa penerima beasiswa bidikmisi menggunakan dana beasiswa bidikmisinya untuk membeli kebutuhan fashion diantaranya ialah membeli baju, sepatu dan tas untuk menunjang penampilan mereka ketika di dalam kampus maupun di luar kampus.

Ketiga, membeli handphone. Kebutuhan lain yang dibutuhkan oleh mahasiswa adalah handphone. Di era modern seperti sekarang handphone sangat dibutuhkan oleh mahasiswa di samping dibutuhkan untuk mempermudah komunikasi, mempermudah mencari materi yang dibutuhkan, digunakan pula untuk menunjang gaya hidup karena handphone zaman sekarang sudah canggih dan mempunyai model yang berfariasi. "Komunikasi merupakan aksi antara dua pihak atau lebih yang melakukan hubungan dalam bentuk saling memberikan tafsiran atas pesan yang disampaikan oleh masingmasing pihak". Secara umum, komunikasi dapat diartikan sebagai proses mengirimkan dan menyampaikan pesan untuk mencapai pemahaman bersama. "Menurut Arminen, komunikasi bergerak (ponsel) memudahkan interaksi antar personal dan mengintegrasikan hubungan komunikasi dengan lingkup ruang lebih luas (global)".

Handphone sangat dibutuhkan oleh mahasiswa sekarang ini karena dengan adanya hanphone dapat memudahkan mahasiswa berkomunikasi dengan teman dan keluarga di kampung halaman, selain itu dengan adanya handphone juga dapat memudahkan mahasiswa mendapatkan informasi yang berkaitan dengan perkuliahan dan memudahkan dalam membantu kahidupan sehari-hari seperti mengiklankan usaha sampingan yang dijalan oleh mahasiswa, dan handphone juga dapat memudahkan mahasiswa untuk order via online berbagai macam kebutuhan seperti makanan dan kendaraan.

Keempat, traktir teman. Mahasiswa penerima beasiswa bidikmisi memanfaatkan dana beasiswa bidikmisinya untuk traktir teman. Mentraktir teman sudah merupakan budaya mahasiswa penerima beasiswa bidikmisi setiap kali uang beasiswa bidikmisi cair karena setiap beasiswa cair teman dari penerima beasiswa meminta traktiran karena mereka beranggapan bahwa mahasiswa penerima beasiswa bidikmisi harus mengeluarkan sedekahnya dengan mentraktir teman dan mereka juga beranggapan bahwa uang beasiswa bidikmisi tidak akan habis jika hanya mentraktir teman. Traktiran yang diberikan oleh penerima beasiswa dalam hal ini berupa makanan.

Kelima, transportasi. Kebutuhan transportasi merupakan kebutuhan non akademik yang dipenuhi oleh mahasiswa penerima beasiswa bidikmisi dengan menggunakan dana 
dari beasiswa bidikmisi. Kebutuhan transpotasi dibutuhkan oleh mahasiswa penerima beasiswa bidikmisi untuk bisa mempermudah akses menuju tempat tujuan. Dengan menggunaan dana beasiswa bidikmisi, mahasiswa penerima beasiswa bidikmisi mencukupi kebutuhan transportasinya yaitu antara lain biaya naik angkutan umum, membeli bensin, perawatan kendaraan bahkan ada mahasiswa yang menggunakan beasiswanya untuk merealisasikan hobbynya yaitu memodif motor yang dimilikinya.

Keenam, pulsa atau paket data. Kebutuhan lain yang dibutuhkan oleh mahasiswa adalah pulsa atau paket data. Selama dalam proses pendidikan di Perguruan Tinggi mahasiswa penerima beasiswa bidikmisi memerlukan pulsa dan paket internet. Pulsa dan paket internet yang dibeli diantaranya digunakan oleh mahasiswa apalagi yang merantau untuk berkomunikasi dengan keluarga dikampung, berkomunikasi dengan teman kampus, mendapatkan informasi mengenai jadwal kuliah, dan adapula yang menggunakannya untuk memudahkan pesan makanan lewat aplikasi dan mempromosikan jualannya dimedia sosial.

Penelitian ini menggunakan teori tindakan sosial yang dikemukakan oleh Max Weber. Mengenai tindakan sosial apabila dikaitkan dengan masalah pemanfaatan beasiswa bidikmisi sebagai penunjang pendidikan oleh mahasiswa penerima beasiswa bidikmisi pada Program Studi Pendidikan Sosiologi Universitas Negeri Makassar jelas ada kaitannya, sebab dalam hal ini segala tindakan yang dilakukan oleh mahasiswa dalam memanfaatkan dana beasiswa bidikmisi yang diterimanya baik dalam keadaan sadar dan terencana. Pemanfaatan beasiswa bidikmisi dilakukan oleh mahasiswa berdasarkan pertimbangan dan pilihan yang sadar, berdasarkan nilai, berdasarkan perasaan atau emosi yang dirasakan tanpa memperhitungkan atau mempertimbangkan rasional tertentu, serta berdasarkan kebiasaan-kebiasaan yang berlaku.

Hasil penelitian ini berbeda dengan penelitian yang dilakukan (Fajrul, 2016) yang menemukan bahwa pengalokasian dana beasiswa bidikmisinya untuk keperluan kuliahnya Serta dampaknya bagi prestasi akademik mahasiswa sedangkan hasil dalam penelitian ini penelitian ini merujuk kepada pemanfaatan beasiswa bidikmisi bukan hanya untuk keperluan kuliah tapi juga untuk memenuhi kebutuhan di luar keperluan kuliah mahasiswa selama menempuh pendidikan dibangku kuliah.

\section{Dampak Pemanfaatan Beasiswa Bidikmisi}

Setiap keputusan yang diambil mempunyai dampak tersendiri, baik itu bersifat baik maupun sebaliknya. Berdasarkan hasil penelitian di Program Studi Pendidikan Sosiologi Universitas Negeri Makassar, dampak pemanfaatan beasiswa bidikmisi pada mahasiswa Program Studi Pendidikan Sosiologi Universitas Negeri Makassar antara lain dampak positifnya yaitu meningkatkan motivasi belajar dan dampak negatifnya yaitu nilai IPK turun dan perilaku konsumtif meningkat.

\section{a. Dampak Positif}

Dampak yang dirasakan oleh mahasiswa penerima beasiswa bidikmisi selama memanfaatkan dana beasiswa bidikmisi yang diterima yaitu meningkatkan motivasi belajar. Motivasi dapat menentukan baik tidaknya mencapai tujuan sehingga semakin besar motivasinya akan semakin besar kesuksesan yang diraih (Solikah, 2008), (Mulyaningsih, 2014). Motivasi sangat dibutuhkan sebagai tenaga penggerak yang ada didalam diri individu untuk melakukan sesuatu. Menurut Winkle motivasi belajar adalah "keseluruhan daya penggerak dalam diri siswa atau mahasiswa yang menimbulkan kegiatan belajar yang menjamin keberlangsungan dari kegiatan belajar dan memberikan 
arah pada kegiatan belajar itu maka tujuan yang dikehendaki oleh siswa atau mahasiswa tercapai (Kiswoyowati, 2011).

Dari hasil penelitian, menunjukkan bahwa dampak yang dirasakan ketika mereka menggunakan dana beasiswa bidikmisinya untuk membeli keperluan akademik seperti buku yaitu mereka termotivasi untuk rajin belajar. Termotivasi untuk rajin belajar karena ada sumber belajar yang dimiliki sehingga materi yang dipelajari mudah didapat dan tugas yang diberikan oleh dosen dapat selesai dikerjakan tepat waktu sehingga IPK mahasiswa penerima beasiswa bidikmisi dapat meningkat atau dapat dipertahankan.

\section{b. Dampak Negatif}

Pada pembahasan ini mengenai dampak negatif dari pemanfaatan beasiswa bidikmisi oleh mahasiswa Program Studi Pendidikan Sosiologi Universitas Negeri Makassar. Dampak pemanfaatannya yaitu nilai IPK mahasiswa menurun dan perilaku konsumtif meningkat.

Pertama, nilai IPK menurun. Nilai IPK mahasiswa penerima beasiswa bidikmisi menurun salah satunya disebabkan karena mahasiswa terlambat mengumpulkan tugas dan terlambat masuk ke kelas. "Faktor yang mempengaruhi hasil belajar terbagi atas dua yaitu faktor internal dan faktor eksternal. Faktor internal mencakup kesehatan, intelegasi dan bakat, minat dan motivasi, serta cara belajar. Sedangkan faktor eksternal mencakup keluarga, sekolah, dan lingkungan sekolah”. Dari hasil penelitian, menunjukkan bahwa nilai IPK mahasiswa penerima beasiswa bidikmisi menurun dibandingkan dengan semester kemarin. Nilai IPK mahasiswa penerima beasiswa bidikmisi mengalami penurunan dibandingkan dengan semester kemarin disebabkan karena mahasiswa terlambat masuk ke kelas, tugas tidak diterima dosen, dan cara belajar yang kurang efektif.

Kedua, perilaku konsumtif meningkat. Dalam hal ini perilaku konsumtif mahasiswa meningkat ketika dana beasiswa bidikmisi yang diterima per semester itu cair. "Perilaku konsumtif adalah perilaku mengkonsumsi barang-barang yang sebenarnya kurang diperlukan (khususnya yang berkaitan dengan respon terhadap konsumsi barang sekunder, yaitu barang yang tidak terlalu dibutuhkan) (Firman, 2019), (Gumulya \& Widiastuti, 2013). Perilaku konsumtif tidak didasarkan pada pada kebutuhan, tetapi didorong oleh hasrat dan keinginan, dimana ada mahasiswa penerima beasiswa bidikmisi lebih banyak menghabiskan dana beasiswa bidikmisinya untuk membeli kebutuhan hidupnya dan kebutuhan lain yang tidak menunjang pendidikan seperti membeli pakaian baru, tas baru, sepatu baru, membelikan orang tua serta adiknya pakaian dan sepatu, bahkan ada mahasiswa yang menggunakan dana beasiswa bidikmisinya untuk traktir teman dan merealisasikan hobynya memodif motor dengan uang beasiswa bidikmisi yang diterima.

Hasil penelitian ini sejalan dengan teori Max Weber (Syukur, 2018) mengenai tindakan sosial dimana pemanfaatan beasiswa bidikmisi sebagai penunjang pendidikan oleh mahasiswa penerima beasiswa bidikmisi pada Program Studi Pendidikan Sosiologi Universitas Negeri Makassar tindakan yang dilakukan oleh seseorang baik dalam keadaan sadar dan terencana yang dipengaruhi oleh lingkungan yang ada disekitarnya sehingga terciptalah suatu tindakan yang berdampak pada mahasiswa tersebut.

Berbeda dengan penelitian yang dilakukan oleh (Kharismayanti, 2017) Penelitian terdahulu lebih merujuk kepada pola penggunaan dana beasiswa pada mahasiswa penerima beasiswa bidikmisi, gaya hidup mahasiswa penerima beasiswa bidikmisi dan perbedaan total pengeluaran konsumsi berdasarkan gaya hidup mahasiswa penerima beasiswa bidikmisi, sedangkan penelitian ini merujuk kepada dampak dari pemanfaatan beasiswa tersebut terhadap mahasiswa. 


\section{PENUTUP}

Pemanfaatan beasiswa bidikmisi pada mahasiswa terbagi atas dua yaitu untuk memenuhi kebutuhan akademik dan non akademik. kebutuhan akademik seperti membeli buku, alat tulis, laptop serta biaya print dan foto copy. Sedangkan kebutuhan non akademik seperti kebutuhan sehari-hari, fashion, membeli handphone, traktir teman, transportasi dan pulsa/paket data. Dari ketiga pemanfaatan beasiswa bidikmisi yang lebih dominan adalah untuk memenuhi kebutuhan non akademik.

Dampak dari pemanfaatan beasiswa bidikmisi terbagi atas dua yaitu dampak positif dan negatif. Dampak positifnya, yaitu meningkatkan motivasi belajar. Sedangkan, dampak negatifnya yaitu nilai IPK menurun dan perilaku konsumtif meningkat.

\section{DAFTAR PUSTAKA}

Fajrul, A. (2016). Mahasiswa Penerima Beasiswa Bidik Misi Srudi Pada Mahasiswa Program Studi Pendidikan Sosiologi. JURNAL SOSIALISASI, 3(1).

Firman, F. (2019). Perilaku Konsumtif Pada Pelajar SMAN 24 Kabupaten Bone. Universitas Negeri Makassar.

Gumulya, J., \& Widiastuti, M. (2013). Pengaruh konsep diri terhadap perilaku konsumtif mahasiswa Universitas Esa Unggul. Jurnal Psikologi Esa Unggul, 11(01), 126900.

Juliardi, M. S. (2017). Universitas Sebelas Maret Bidikmisi Applicant's Classification using C4. 5 Algorithm. ITSMART: Jurnal Teknologi Dan Informasi, 6(1), 16-23.

Kharismayanti, S. I. (2017). Pola penggunaan dana dan gaya hidup mahasiswa penerima beasiswa bidikmisi di fakultas ekonomi universitas negeri Yogyakarta. Jurnal Pendidikan Dan Ekonomi, 6(4), 400-410.

Kiswoyowati, A. (2011). Pengaruh motivasi belajar dan kegiatan belajar siswa terhadap kecakapan hidup siswa. Portal Jurnal Universitas Pendidikan Indonesia, 2(1), 12-16.

Mulyaningsih, I. E. (2014). Pengaruh interaksi sosial keluarga, motivasi belajar, dan kemandirian belajar terhadap prestasi belajar. Jurnal Pendidikan Dan Kebudayaan, 20(4), 441-451.

Rachmawaty, D. T. (2016). Pengaruh beasiswa Bidikmisi terhadap prestasi belajar mahasiswa penerima beasiswa Bidikmisi di UIN Syarif Hidayatullah Jakarta.

Solikah, S. N. (2008). Hubungan Antara Minat Dengan Motivasi Belajar Mahasiswa Dalam Mengikuti Pembelajaran Praktik Dilaboratorium Keterampilan Keperawatan Universitas Muhammadiyah Surakarta. Universitas Muhammadiyah Surakarta.

Syukur, M. (2018). Dasar-Dasar Teori Sosiologi. PT. Rajagrafindo Persada. 